\title{
HOLIDAYS TO THE HELLS OF EARTH - TAKING RISK AS A DARK TOURIST?
}

\author{
Zsuzsanna MARTONa , Ildikó ERNSZTa ${ }^{\text {, Zoltán BIRKNER }}$ \\ aUniversity of Pannonia Nagykanizsa Campus, marton.zsuzsanna@uni-pen.hu, ernszt.ildiko@uni-pen.hu, \\ birkner.zoltan@uni-pen.hu
}

Cite this article: Marton, Z., Ernszt, I., Birkner, Z. (2020). Holidays to the Hells of Earth - Taking Risk as a Dark Tourist? Deturope. 12(1), 136-153

\begin{abstract}
More and more tourists have visited places linked to mortality, catastrophes, or distressing events that led to the increased popularity of the niche market called dark tourism. Dark tourism cannot be considered as a new phenomenon; however, the interest in destinations associated with death is undoubtedly soaring. In the recent years, especially as a consequence of the considerably huge power of (social) media, dark tourism has gained more attention again, not only of the tourists but also of the academic researchers. Most of the time, ethical and moral issues are mentioned concerning dark tourism, but the risks threatening dark travelers are also crucial and important. The role of tourism safety and security perspective has got more interest and importance due to the terror attacks, or natural disasters that took place in the last decades. In spite of the disasters, tourists are willing to take a risk - as far as they are aware of them, and visit dangerous places. This paper aims to figure out the relationship between risk perception and dark tourism by combining and linking the relevant theories together, and exploring tourists' attitudes towards dark tourism and different travel risks based on a Hungarian sample.
\end{abstract}

Keywords: risk perception, tourism safety and security, dark tourism

\section{INTRODUCTION}

In spite of the fact that the number of unexpected events like natural catastrophes or terror attacks has increased in the past decades, world tourism has still shown continuous expansion (UNWTO, 2019). Shocks and crises becoming more frequent have brought several changes in the tourism sector; tourism safety and security issues get into the spotlight and grab the attention both of the supply and the demand side of the industry. Not only the tourism organisations, but also service providers put more emphasis on prevention and risk management.

Catastrophes can also bring about significant changes in the travel decision-making process of tourists. It can happen to popular tourist destinations with high prestige that tourists completely turn away from them.

The sense of tourists' risk perception has become more refined, often excessively sensitive due to the unpredictable time and location of tourism disasters. Judging the degree of the real risk is quite difficult for the people since media often exaggerates the facts or simply gives 
incomplete information to the public. The image of tourist destinations suffered from catastrophes usually decline, which results in decreasing tourist arrivals and tourism receipts.

Numerous tourists belong to the group of risk-averse or neutral people, who keep off risky places. However, there is a niche segment of them who does seek for destinations having a dark chapter in their past. Some of the motivations could be curiosity, commemoration, educational purpose, or simply the search for risk and danger (Cohen, 2011; Yoshida, Bui, \& Lee2016). Surprisingly, this 'dark' market is continuously expanding; the stunning view and landscapes, cultural and historical attractions are not satisfying the tourists' needs and wants anymore. Battlefields, scenes of earthquakes, crimes, or nuclear disasters are becoming more and more fashionable destinations. This phenomenon or trend started flourishing, primarily, due to the high media presence of these places on video and image sharing platforms, as well as, in online TV shows, series. Consumer behaviour is influenced by media far more vigorously than ever before.

Several blogs, news have dealt with the phenomenon of dark or catastrophe tourism, and even businesses have recognized the market potential hidden earlier. Travel agencies, hotels prefer to promote their services with contents linked to horrifying disasters. Ethical and moral issues may arise from the side of service providers and dark tourists, too.

Academic studies (Stone \& Sharpley, 2013; Stebbins, Rohek, \& Sullivan, 2006; Rucinska, 2016) also focus on the immoral side of dark tourism and the deviant behaviour of tourists. However, a catastrophe tourist does not equal to a deviant person. Independently from deviance, a catastrophe tourist might take a higher risk; therefore, its personal safety is more exposed to danger.

Dark tourism has been studied from different approaches (e.g., type of the place, motivations, type of the experience) so far (Light, 2017). However, tourism safety and security perspective of dark tourism was not construed before, so this study attempts to conceptualize the linkage between tourism safety and dark tourism. On the one hand, the theoretical overview of dark tourism and tourism safety will give the frame of the paper; on the other hand, the results of empirical research conducted with 206 Hungarian people will prove the importance and actuality of the two main research fields and their connections. The quantitative survey seeks to explore the attitude of tourists towards visiting death-related destinations and their risk perception in travel decision, generally. 


\section{THEORETICAL BACKGROUND}

\section{Terminology of dark tourism}

Why do people like travelling to places strongly related to death and sadness? Should tourists feel ashamed about this? How weird is it that, as a result of TV shows (e.g., Chernobyl by HBO, Dark Tourist by Netflix), masses of people flock to the scenes of disasters? That is strange or not, to be shamed or not, catastrophe tourism is flourishing, far more people put these destinations on their bucket list.

Dark tourism is not a new phenomenon, after all. According to Stone (2005), it is 'an old concept in the new world' (Farmaki, 2013). The Roman gladiatorial games, the public execution of Louis XVI, or visits to the battlefield of Waterloo are all early evidence of the fact that people have been interested in sites of deaths (Stone \& Sharpley, 2008, Seaton, 1999). Visiting destinations related to the scenes of wars of atrocities actually belong to heritage tourism in a broader context. Dark tourism can be interpreted in a complex way; its understanding is still quite limited because of the different interpretations and perspectives deriving from various motivators and socio-cultural factors (Stone, 2005).

The relationship between death and tourism was already in focus of studies, for instance, in a heritage tourism perspective (Uzell, 1992; Rojek, 1993; Tunbridge, \& Asworth's, 1996; Dann, 1994; Prentice, 1993). Rojek (1993) defined the term 'blackspots' or 'grave tourism' (including pilgrimage sites like cemeteries) being fundamentally different from disaster sites and disaster tourism. Later, the concept was clarified further, 'nostalgic' and 'sensation' sites were identified (Rojek, 1997). Foley and Lennon (1996:198) coined first the term 'dark tourism' such as 'the presentation and consumption of real and commodified death and disaster sites'. In parallel, Seaton (1996) labelled the phenomenon as thanatourism. The real difference between the two terms still remains unclear; they are used interchangeably. Regarding the media presence, thanatourism has got less negative associations than dark tourism has got (Friedrich \& Johnston, 2013). Blom (2000) highlights the importance of tourist experience concerning dark tourism. The author associated the new term 'morbid tourism' with sudden violent death.

Different terms (e.g., dark tourism, disaster tourism, thanatourism) and perspectives are used for the activities linked to deaths and disasters; various theory concepts have been born in this research field. The main concepts are summed up in Tab. 1. 
Table 1 Concepts related to dark tourism

\begin{tabular}{|l|l|l|}
\hline \multicolumn{1}{|c|}{ Concept (term) } & \multicolumn{1}{|c|}{ Definition } & Author(s) \\
\hline Black spot, grief tourism & $\begin{array}{l}\text { Focus on the commercial development of grave } \\
\text { sites and sites in which celebrities or lots of } \\
\text { people have met with sudden and violent deaths } \\
\text { (e.g. highways). }\end{array}$ & Rojek (1993:136) \\
\hline Dark tourism & $\begin{array}{l}\text { Tourism to sites associated with death, disaster } \\
\text { and tragedy in the 20 } \\
\text { of century for the purposes }\end{array}$ & $\begin{array}{l}\text { Lennon and Foley } \\
(1997: 155)\end{array}$ \\
\hline Thanatourism & $\begin{array}{l}\text { Travel to sites to encounter actually or } \\
\text { symbolically with death (violent death). }\end{array}$ & Seaton (1996) \\
\hline Dark tourism & $\begin{array}{l}\text { Visit to places 'associated with death, suffering } \\
\text { and the seemingly macabre' }\end{array}$ & Stone (2006:146) \\
\hline Morbid tourism & $\begin{array}{l}\text { Tourism focusing on sudden violent death, and } \\
\text { attraction focused artificial morbidity-related } \\
\text { tourism. }\end{array}$ & Blom (2000:32) \\
\hline
\end{tabular}

Source: own compilation

As the summary table presents, the terms have changed over the years. Yet, all approaches put death into the centre of the concept. Due to the complexity and the diversity of this niche market in the contemporary tourism landscape, it is quite hard to find the sharp distinctions between disaster tourism and dark tourism.

Different tourist motivations also contribute to the broad interpretation of the phenomenon. In the travel decision-making process, push and pull factors play an important role. Push factors actually those internal drivers, which motivate people to travel. Socio-psychological, cultural motives, personality, past experiences, memories have influences on people's decisions. Pull factors try to grab the attention of potential tourists and attract them to the destination. (Crompton, 1979). Understanding dark tourists' travel motivations have never been easy, although many exploratory researches have dealt with them. Light (2017) carried out a broad qualitative research summarizing the related studies so far (Fig. 1). 
Figure 1 Main motives for dark tourism

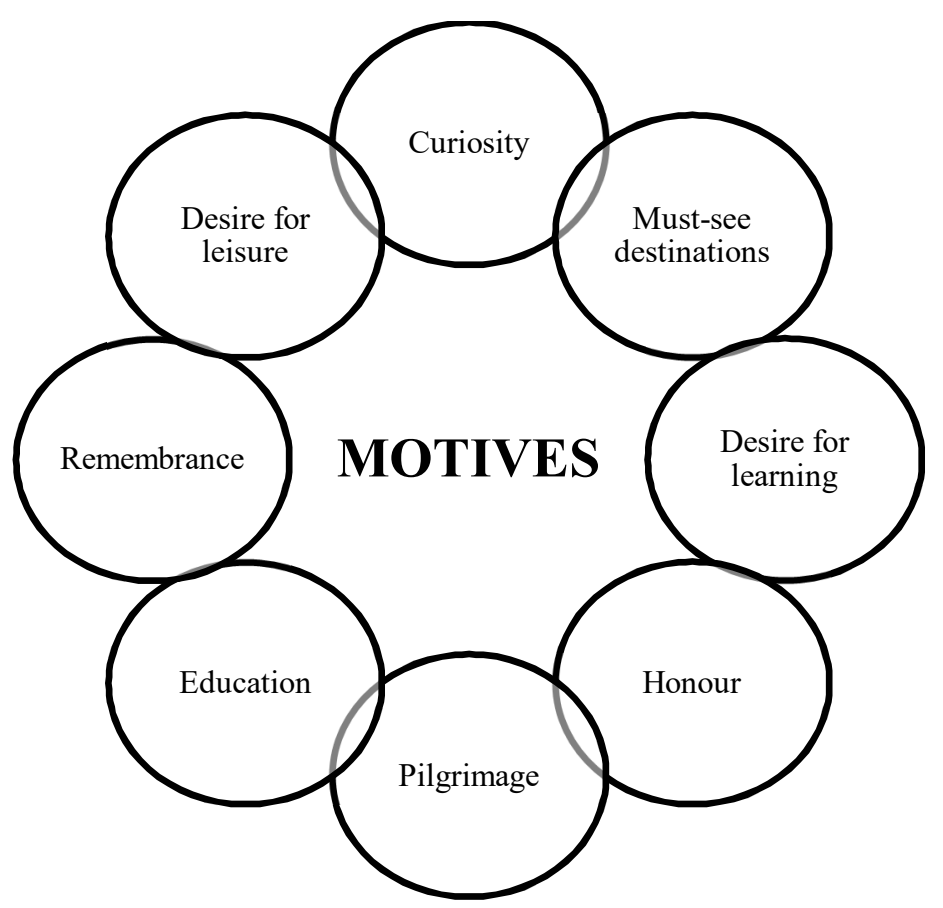

Source: own compilation based on Light (2017)

According to previous studies, the push factors - e.g., desire to learn, explore or honour - were dominating, however, push factors - especially the power of social media and online documentaries- attract more dark tourists than ever before. Nobody has thought that a movie series had such a huge impact on the tourism market by enlivening dark tourism. The constant social-media usage (Instagram, Facebook) can significantly alter the travel trends, too. By this media wave, both the private users and the service providers joined the circulation to promote the dark side of tourism.

\section{Brief insights into dark sites and relates services}

Touristic sites attract thousands of visitors worldwide. One of the most important attractions are museums displaying tragic events and their victims: e.g., Murambi Museum in Ruanda, the places of massacres in Cambodia or the International Slavery Museum in Liverpool, the Memorial and Museum Auschwitz-Birkenau Former German Nazi Concentration and Extermination Camp. Besides these museums, different tours into the slums of cities (Dharavi, Mexico City, Rio de Janeiro), and the cemeteries of cities (e.g., Pere-Lachaise cemetery in Paris) are also offered by service providers. (Remenyik \& Dávid, 2014). The „dark offer“ has also reached the hotel industry: in Sarajevo in the War Hostel, guests can witness the feelings 
and memories of the former Jugoslavian war; with no electricity, running water; but there is war breakfast (Hostelworld, 2020). In 2013 Booking.com had a Halloween campaign with the title „Stay if you dare“ offering haunted hotels (Turizmus Online, 2013).

According to Seaton, the sacralization of „dark places“ has a process: as first step tourism tumbles on the site; then the place becomes a kind of sanctuary, it is enhanced, and finally, it is sacralized (Remenyik \& Dávid, 2014). The sacralization of dark tourism sites in Hungary has not happened yet (Tilkovszky, 1998). In Hungary, dark tourism is still in its infancy; some touristic enterprises have already recognized the market potential on a domestic level. For instance, in the forests of Pilis and Visegrád (Fig. 2), there are many memorial sites related to bloody murders or fatal accidents from history (Tenczer, 2019). In Hungary, rather the term 'catastrophe tourism' is in the public eye, which encompasses both dark and disaster tourism.

There are some museums falling into this category, and also some touristic service providers, who have an offer on this field. Most dark tourism sites in Hungary are located in the capital, in Budapest.

The Holocaust Memorial Center - linked to the Páva Street Synagogue - offers special permanent and periodic exhibitions, even museum pedagogical programs for the purpose of education (Holokauszt Emlékközpont).

The House of Terror Museum, ,is a monument to the memory of those held captive, tortured, and killed in the building“, where can also be a symbol of terror of the fascist and the communist regime as well (Terror Háza Múzeum).

In the Fimei Road Graveyard, the most famous and respected members of the former Hungarian society were buried: politicians, artists, musicians, poets, writers. Furthermore, most tombstones have an art historical value as well. There are thematic, guided walks in the cemetery with the following titles: e.g., Women, muses, fates; the most famous gypsy primates; artists‘ plot; inventors and engineers (Fiumei úti sírkert).

In the countryside, the number of dark tourism sites is even more limited. The Recsk National Memorial Site stands as a memory of the forced labour camp established by the communist totalitarian regime. In Mohács, a national memorial site was set up on the place where the Hungarian troops have lost their battle against the invading Ottoman troops in 1526, and more thousands of soldiers have died in 1.5 hour (Mohácsi Nemzeti Emlékhely). On the western part of Hungary, in Páka a $630 \mathrm{~km}$ long Cold War bunker system was revealed, which once stretched from the Austrian to the Romanian border (Murarégió Turisztikai Portál). 
Figure 2 Dark sites in Hungary

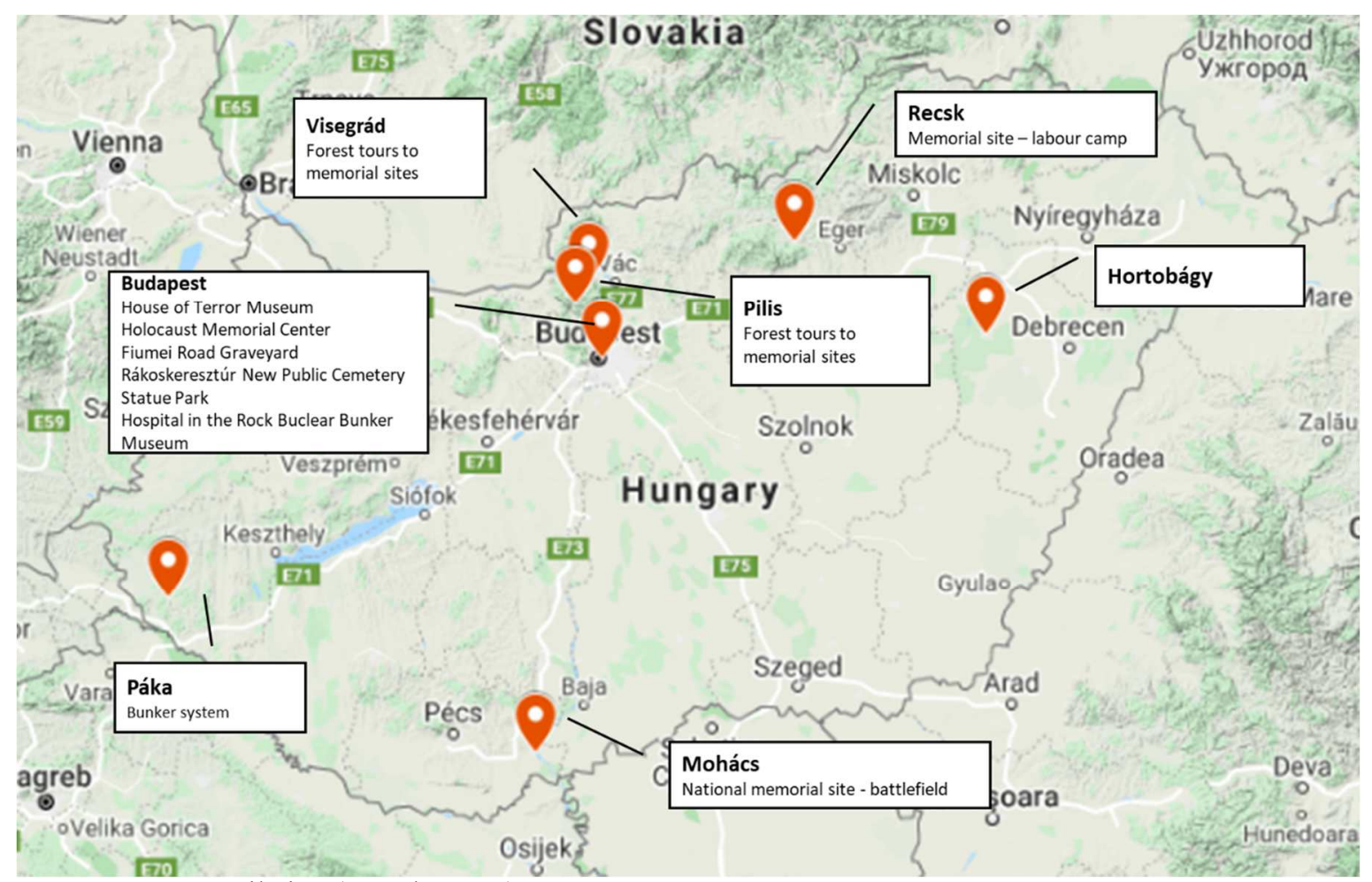

Source: own compilation (Google maps)

However, there are more and more alternative tours that show the dark features of a certain place. In Budapest, alternative service providers offer bunker tour in Csepel Factory, cellar tour in Köbánya with memories from the $2^{\text {nd }}$ World War (from Budapest Scenes). Tourists and also locals can walk on the tours and can hear „Bloody Tales from within the Castle Walls“ (from Budapest Mysterium Tours), Crime and history in the Buda Castle - with Willie Slick tour, It is Rumored - Criminal histories in Budapest (from Imagine Budapest). (Tab. 2)

Table 2 Some examples of dark, alternative walking tours in Budapest

\begin{tabular}{|l|l|}
\hline SERVICE PROVIDER & THE NAME OF THE ALTERNATIVE \\
& DARK WALKING TOUR \\
\hline Budapest Scenes & Bunker Tour in Csepel Factory \\
& Cellar Tour in Köbánya \\
\hline Budapest Mysterium Tours & Bloody Tales from within the Castle Walls \\
& Labyrinth of Buda Castle \\
\hline Imagine Budapest & Crime and history in the Buda Castle - with \\
& Willie Slick tour \\
& It is Rumored - Criminal histories in Budapest \\
& The Secrets of Depth: A Visit to an \\
& Underground Facility \\
\hline Fiumei Road Graveyard & Walking tours in the cemetery: \\
& Women, Muses, Faits \\
& The Most Famous Gypsy Primates \\
& Artists plot \\
& Iinventors and engineers \\
\hline
\end{tabular}

Source: Budapest Scenes, Budapest Mysterium Tours, Imagine Budapest, Fiumei Road Graveyard 


\section{Basics of tourism safety and security}

$11^{\text {th }}$ September (9/11) has been a tragic and meaningful date for almost two decades. A terror attack, which brings back memories year by year, and which changed the tourism, fundamentally. Safety and security issues and measurements suddenly came into view and became extremely important. This also induced several academic pieces of research (Fall \& Massey, 2005; Henderson, 2003; Massey, 2005; Péter, Németh, \& Lelkóné, 2018; Péter et al., 2019 ) in the field of tourism safety and crisis management. Nevertheless, the focus initially was on terror attacks in association with tourism safety and security, but the interpretation cannot be limited only to these crises. Natural catastrophes (earthquakes, bushfires, hurricanes), epidemics (Ebola), cyber-attacks, food safety, crimes on cruise ships, local uprisings are some examples picked out from the numerous threats possibly occurring during travel. The wide range of topics affiliated with tourism safety and security proves the heterogeneous and diverse nature of the research field.

On the international level, the concept building of tourism safety and security theory has integrated different research fields, like for example risk management, consumer behaviour, risk perception, travel decision-making process, destination image or marketing communication. The theoretical concept of risk perception is the most correlated approach to tourism safety and security, and helped to ground the concept. Before 9/11 attack, the term 'perceived risk' had had the focus on time, money, satisfaction, and psychology, and by the horrible crisis, the emphasis was put on the physical risk. (Yang \& Nair, 2014; Fuchs \& Reichel, 2011).

In the travel-decision making process, the chance of risk plays a dominant role. Risks threatening tourists can be the followings (Mansfeld \& Pizam, 2006; Breda \& Costa, 2005; Karl \& Schmude, 2017; Sönmez \& Graefe, 1998, Fuchs \& Reichel, 2011):

- Physical - health risk (e.g. infections due to polluted water or ski accident),

- Local safety (e.g. crimes, sexual assault)

- Time risk (e.g. travel was a waste of time),

- Financial risk (e.g. low level of value for money),

- Natural catastrophe - climate related risk (extreme weather conditions, earthquake),

- Political instability (e.g. uprisings, riots),

- Social risk (e.g. travel condemned by others),

- Psychological risk (e.g. lack of self-actualization by travel),

- Terrorism. 
The risk types can threat independently from each other, but often occur at the same time.

Dark tourism from safety and security perspective - The Case of Chernobyl

The HBO Chernobyl show premiered in spring 2019 tells and dramatizes the story of the nuclear plant disaster in Chernobyl in April 1986, which has been considered as one of the most catastrophic man-made disasters in the history. Before the appearance of the show, Chernobyl did attract dark tourists, however symbolized rather the negative part of Ukraine's brand (Deerwester, 2019). But the time brought changes and made it the part of uniqueness of Ukraine and the brand equity.

Since the TV show started, the growing interest in Chernobyl and Pripyat has been enhanced. According to the predictions, the number of the tourist arrivals at the exclusion zone may be twice more than this year, and reach the 150,000 visitors (Deerwester, 2019).

According to the new trend, not only the tourists want to visit dark sites who did before, but also those people desire for dark tourism, who were just astonished by an Instagram photo or a TV series. The number of dark tourists has started to mushroom in the recent years, especially thanks to documentaries. Service providers (travel agencies, accommodations) all want to benefit from this market potential.

Tourists flow to the black spots, enjoy the adventure, the opportunity of exploration and mystery, and of course, they document everything on selfies or in video blogs. Nevertheless, is there anybody considering the real degree of danger and risk? Before a simple travel, people usually weigh up the pros and cons of a destination and the possibly occurring risk. Why did many tourists become less risk-sensitive than before? Maybe they do not think about the risks at all, because social media highlight the other appeals of dark tourism and neglect tourism safety and security issues.

During a Chernobyl tour, tourists are excited to wear protective clothes, to grab their own dosimeter to measure radioactivity, meanwhile they have no thoughts about the risks. Here are some of the rules what tourists have to meet during the guided tour (USA Today, 2019):

- tetanus vaccination before going to the zone,

- wearing protective-clothing,

- no food can be consumed,

- no touch on the objects, animals... etc.,

- on windy, dry days, wearing mask is proposed due to the dust containing radioactive particles. 
The opinions about the safety of the destination differ, but the authors definitely think that the possible risks cannot be passed by. Regarding the theoretical background of tourism safety and security, the following types of risk can be associated with dark tourism (Tab. 3) based on the lessons learned from the Chernobyl case.

Table 3 The risk types strongly associated with dark tourism - based on the case of Chernobyl

\begin{tabular}{|l|l|}
\hline \multicolumn{1}{|c|}{ Risk category } & \multicolumn{1}{c|}{ Example } \\
\hline Health & Radiation (through touch or inspiratory) \\
\hline Physical & $\begin{array}{l}\text { Surrounding equipment can cause physical injury (health related } \\
\text { as well) }\end{array}$ \\
\hline Psychological & $\begin{array}{l}\text { Fear from radioactivity, fear from the prestige of being a dark } \\
\text { tourist }\end{array}$ \\
\hline Satisfaction & $\begin{array}{l}\text { Desire for freedom during the tour, but many rules have to be } \\
\text { met }\end{array}$ \\
\hline
\end{tabular}

Source: own compilation

The case of Chernobyl is one of the examples representing the actuality of the research field of tourism safety, referring to dark tourism.

\section{DATA AND METHODS}

The research problem of the paper is to find empirical proof of the relationship of the tourists' attitudes toward dark tourism and their general risk perception concerning travel. The following research questions were defined:

RQ1: How is the attitude of the Hungarian respondents towards visiting dark tourism places during their travels?

RQ2: Is there any influence of the risk perception (fear) on decision and attitude? A quantitative survey was conducted with more than two hundred Hungarian people as a part of an omnibus research focusing on the tourists' consumer behavior in the field of tourism. The questionnaire consisted of multiple answer questions and statements for evaluation on 5point Likert-scale. The popularity and awareness of dark tourism among Hungarians were investigated by the attitude towards visiting places of natural catastrophes or historical places associated with death or mortality.

The questionnaire survey was carried out by the snowball sampling technique that resulted in a non-representative sample. This fact also can be regarded as one of the limitations of the research.

The research sample made up of 206 people participants. 74 percent of the respondents was 
female, 26 percent of them was male. 65 percent of them travels once or twice a year, 19 percent of them makes trip three or four times, and those, who travel more than four times per year, represent 15 percent of the sample. Only 2 percent of the respondents said that did not travel every year. (Tab. 4)

Table 4 Profile of the research sample

\begin{tabular}{|c|c|c|c|c|c|}
\hline & $\mathbf{n}$ & $\%$ & & $\mathbf{n}$ & $\%$ \\
\hline Age & & & Gender & & \\
\hline $18-25$ years & 94 & $45.60 \%$ & female & 153 & $74.35 \%$ \\
\hline $26-35$ years & 32 & $15.00 \%$ & male & 53 & $25.7 \%$ \\
\hline $36-45$ years & 45 & $21.80 \%$ & & & \\
\hline $46-55$ years & 20 & $9.70 \%$ & Education & & \\
\hline $55-65$ years & 12 & $5.80 \%$ & Primary school & 6 & $2.9 \%$ \\
\hline \multirow[t]{2}{*}{$>65$ years } & 4 & $1.90 \%$ & Secondary school & 133 & $64.6 \%$ \\
\hline & & & College/ university & 64 & $31.1 \%$ \\
\hline Occupation & & & Postgraduate/ PhD & 3 & $1.5 \%$ \\
\hline Student & 71 & $34.50 \%$ & & & \\
\hline Entrepreneur & 5 & $2.40 \%$ & Frequency of travel & & \\
\hline Public sector employee & 42 & $20.40 \%$ & not every year & 3 & $1.5 \%$ \\
\hline Private sector employee & 82 & $39.80 \%$ & 1-2 times a year & 133 & $64.6 \%$ \\
\hline Retired & 4 & $1.90 \%$ & 3-4 times a year & 39 & $18.9 \%$ \\
\hline Other & 2 & $1.00 \%$ & $>4$ times a year & 31 & $15 \%$ \\
\hline
\end{tabular}

Source: own compilation

To reveal the basic characteristics of the sample, descriptive statistics such as frequency tables and cross tabs were used. The relationships between variables was analyzed based on ANOVA analysis run by SPSS IBM 22 software. For the purpose of visual illustration, bar charts were created.

\section{RESULTS AND DISCUSSION}

Based on the theoretical overview, we can conclude that dark tourism can pervade different tourism types and destinations. But, in most cases, dark tourists visit historical places (memorial sites, cemeteries, museums) and natural sights strongly connected to death and mortality. The analysis of the main motivation and most preferred tourism types by the respondents shows that the respondents travel most frequently from the following purposes: visiting friends and relatives, $($ avg. score $=3.60)$, visiting waterside holiday destinations (avg. score $=3.50)$, and taking sightseeing tours (avg. score $=3.27$ ). The popularity of historical and cultural attractions (e.g., religious places, pilgrimage) has not been really attractive based on the sample, especially 
among respondents aged under 35, since approximately 90 percent of them never travel for this purpose.

Concerning the travel decision-making and destination choice of the survey participants, the factors playing a role in the choice, were also considered. In this case, only those factors are analyzed that can theoretically be linked to dark tourism such as novelty power, climate adventure factor, and so on (Fig. 3).

Figure 3 Importance of factors in travel decisions

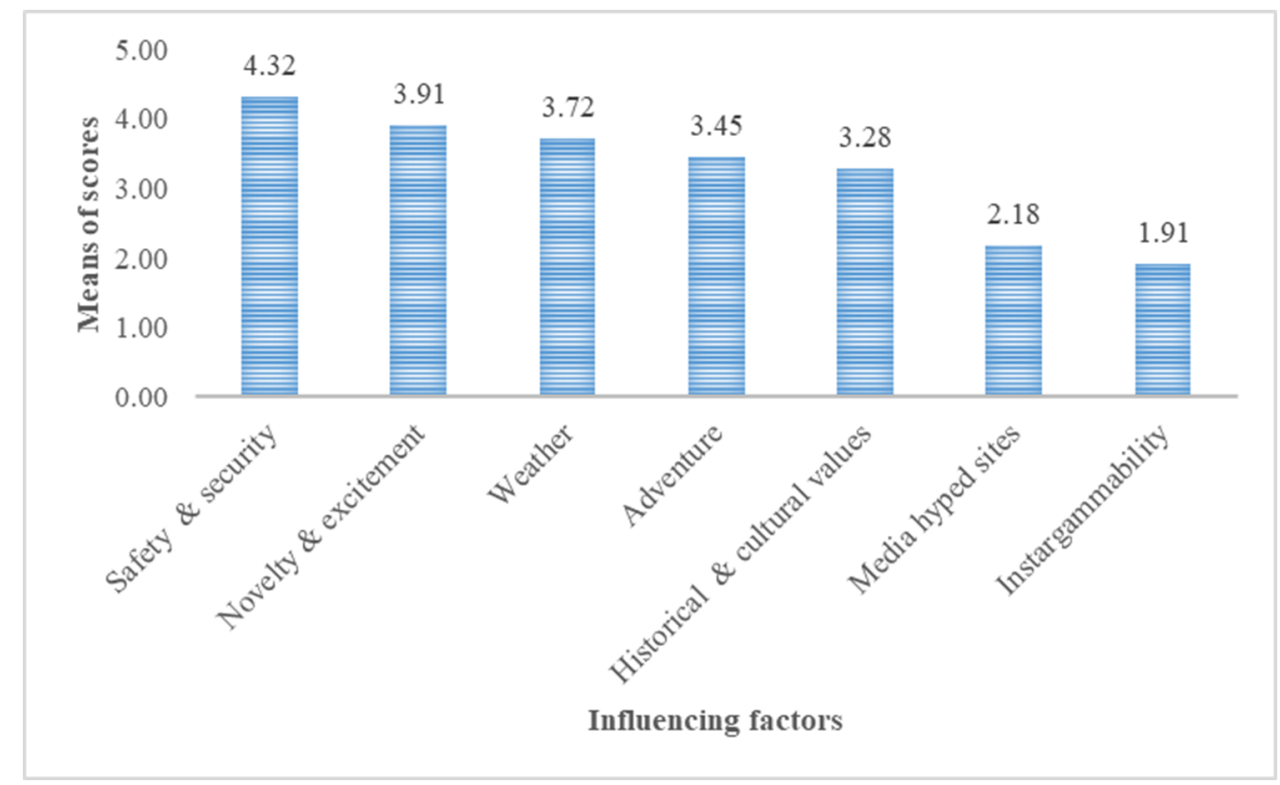

Source: data created by the Authors

Fig 3 represents that safety and security of a destination are far more important for the respondents (average score is 4.32), while novelty and excitement are also crucial. In the decision-making process, based on the average score (3.45) of 'adventure' is rather important, like the historical and cultural values of a destination. By running the One-way ANOVA analysis and $\mathrm{F}$ probe, it turned out that there is a significant difference on 5 percent significance level between age groups in terms of the following variables: novelty $(p=0.004)$, historical values $(p=0.009)$ and Instagrammability $(p=0.000)$. Fisher's LSD analysis proves that the biggest gap is between age groups in terms of Instagrammability, hence all age groups' means significantly differ $(\mathrm{p}<0.05)$ from the mean of the youngest $(18-25)$ group.

Due to the power of social media platforms (e.g., Instagram or Facebook), dark tourism sites gain bigger popularity that has effects rather on younger generations. Instagram posts and 
photos often influence youngsters' behavior and consumer decision. Our research results can also justify this fact, since the proportion of the Instagram (85\%) or Facebook (97\%) users are the highest in the age group 18-25, followed by respondents aged $26-35$ with 40 and $83 \%$, respectively. The associations between the variables are significant in both cases (Instagram and Facebook usage), and the Cramer's $\mathrm{V}\left(\mathrm{V}^{\mathrm{FB}}=0.42\right.$ and $\left.\mathrm{V}^{\mathrm{Inst}}=0.59\right)$ means a substantially strong relationship between social media usage and age (groups).

Respondents all find safety and security issues quite important in their travel decision independently from age based on the average scores (Tab. 5).

Table 5 Means of the age groups concerning the importance of 'Safety and Security' in travel decision

\section{Descriptives}

Importance in travel decision safety and security

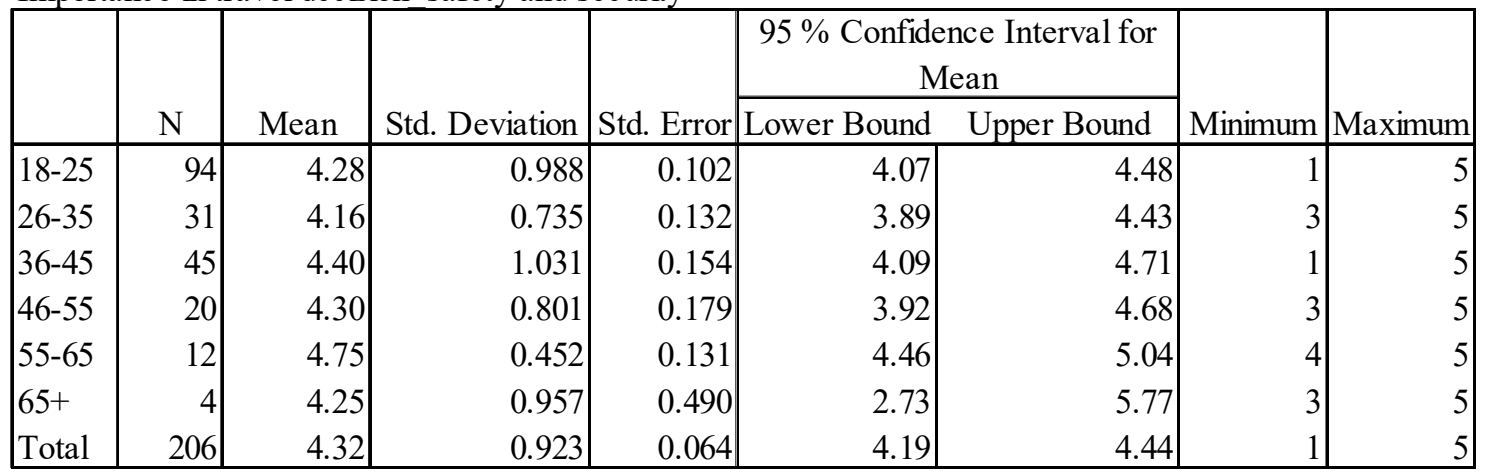

Source: data created by the Authors in SPSS

According to ANOVA analysis, the means of the different age buckets do not show any significant difference $(\mathrm{p}=0.54>0.05)$. Considering the travels to dark sites that might be risky, only 13 percent of the people would travel to touristic sites being famous for natural catastrophes, 73 percent of them would avoid these destinations, as much as possible. The attitude toward places associated with death - independently from the fact that it is a memorial site - the proportion of those would almost totally avoid visiting there is similarly high - it is 78 percent. Those people who are interested in these dark places represent only 10 percent of the sample. There is 10-15 percent in both cases (catastrophe or terror attack sites), who can regard these travels in a neutral way. The attitude and willingness towards visiting dark places does not depend on the fact of how important the safety is during their trips based on ANOVA analyses (Tab. 6 and 7) 
Table 6 ANOVA table for the attitude towards visiting places of natural catastrophes according to the importance of safety

ANOVA

natural catastrophes
\begin{tabular}{|l|r|r|r|c|c|}
\hline & $\begin{array}{r}\text { Sum of } \\
\text { Squares }\end{array}$ & df & Mean Square & F & Sig. \\
\hline Between Groups & 3.437 & 4 & 0.859 & 1.655 & 0.162 \\
Within Groups & 104.311 & 201 & 0.519 & & \\
Total & 107.748 & 205 & & & \\
\hline
\end{tabular}

Source: data created by the Authors in SPSS

Table 7 ANOVA table for the attitude towards visiting places of terror attacks according to the importance of safety

ANOVA

terror attack

\begin{tabular}{|l|r|r|r|c|c|}
\hline & $\begin{array}{r}\text { Sum of } \\
\text { Squares }\end{array}$ & df & Mean Square & F & Sig. \\
\hline Between Groups & 1.198 & 4 & 0.300 & 0.700 & 0.593 \\
Within Groups & 86.011 & 201 & 0.428 & & \\
Total & 87.209 & 205 & & & \\
\hline
\end{tabular}

Source: data created by the Authors in SPSS

Generally, the interest in making trips to places connected to catastrophes (natural disaster or terror at) is quite low (avg. score 1.95 and 1.79). However, the age group of 18-25 years is outstanding among the respondents. ANOVA analysis proves that the youngest age group with the highest attitudes score significantly differs from the older people. (Tab. 8)

Table 8 ANOVA table for the attitude towards visiting dark places according to age groups

ANOVA

\begin{tabular}{|c|c|c|c|c|c|c|}
\hline & & $\begin{array}{r}\text { Sum of } \\
\text { Squares }\end{array}$ & df & Mean Square & $\mathrm{F}$ & Sig. \\
\hline \multirow{3}{*}{$\begin{array}{l}\text { visiting sites of natural } \\
\text { catastrophes }\end{array}$} & Between Groups & 55.496 & 5 & 11.099 & \multirow[t]{3}{*}{9.998} & \multirow[t]{3}{*}{0.000} \\
\hline & Within Groups & 222.02 & 200 & 1.110 & & \\
\hline & Total & 277.515 & 205 & & & \\
\hline \multirow{3}{*}{$\begin{array}{l}\text { visiting sites of memorial sites } \\
\text { of terror attacks, murders }\end{array}$} & Between Groups & 44.099 & 5 & 8.820 & \multirow[t]{3}{*}{7.115} & \multirow[t]{3}{*}{0.000} \\
\hline & Within Groups & 247.925 & 201 & 1.340 & & \\
\hline & Total & 292.024 & 205 & & & \\
\hline
\end{tabular}

Source: data created by the Authors in SPSS 


\section{CONCLUSION}

Understanding consumer behavior has never been easy for researchers. The motivation of dark tourists has already been studied in many perspectives. However, the investigation of the attitude of people (tourists) toward it is a new way of approaching the topic. Based on our sample, the popularity of and identification with dark tourism among the Hungarians are said to be low. Safety risks might have an effect on travel decisions; hence, the majority of the respondents find the consideration of safety and security quite important before travelling. However, the low popularity of dark tourism cannot be obviously deduced from the safety and security issues. ANOVA analysis does not prove the statistical relationship either. Therefore, more and deeper analyses are needed to reveal the causes of the low popularity of dark tourism. However, those tourists who visit these sites, maybe, they are simply not aware of the possible dangers of these dark sites. Therefore they do not associate these attractions with fear and risks. Ethical and moral questions can also arise, that can be connected to psychological and social risks, for instance. The power of social media and the degree of risk-taking, and the related consciousness and responsibility all raises many new questions.

\section{SUMMARY}

Although most people consider safety and security issues crucial, when making a holiday, there are also more and more tourists who are keen on dangerous adventures with a dark background. A growing number of tourists visit places linked to mortality, catastrophes, or distressing events that led to the increased popularity of this niche market.

Dark tourism cannot be considered as a new phenomenon; however, the interest in destinations associated with death is undoubtedly soaring. It can even be stated that on the international level, the market is booming: it serves the needs of a larger number of tourists year by year. The motivation drivers for dark tourism are not special; people choose dark sites from curiosity, desire for learning and understanding history, or just meet up with their friends.

In the recent years, especially as a consequence of the considerably huge power of (social) media, dark tourism has gained more attention again, not only of the tourists, but also of the academic researchers.

Dark places frequently appear on video and image sharing platforms, on online TV shows, series; and consumer behavior is influenced and manipulated by media much more, than ever before.

Most of the time, ethical and moral issues are mentioned concerning dark tourism, but the risks threatening dark travelers are also crucial and important. The role of tourism safety and security perspective has got more interest and importance due to the terror attacks or the natural disasters took place in last decades. In spite of the disasters, tourists are willing to take risk - as far as they are aware of them, and visit dangerous places. Dark tourism is not necessarily a leisure-typed travel, it has to be taken seriously by considering the potential risks, as well.

This paper aimed to figure out the relationship between risk perception and dark tourism by combining and linking the relevant theories together and exploring tourists' attitudes towards dark tourism and different travel risks based on a Hungarian sample.

The findings of our research show that safety and security issues are crucial factors when making travel decisions, which can determine the attitude towards "dark" destinations. Based on a Hungarian sample involving 206 respondents, the percentage of respondents who would travel to sites of natural catastrophes is extremely low, only 13\%; meanwhile, $73 \%$ of them would definitely avoid these destinations. Similar results were detected regarding the places associated with death: $78 \%$ of the respondents reject taking these places as a possible holiday or excursion destination. The younger generation (between 18-25 years) shows more interest in these morbid, sometimes definitely dangerous places than older respondents according to 
ANOVA analysis. However, there is no statistical relationship between the attitude of visiting dark sites and the importance of safety and security in the travel decision. Currently, it is obvious that dark tourism in Hungary is still in its infancy, and other causes have to be looked for in further researches.

\section{REFERENCES}

Birkner, Z., Marton, Z., \& Keller, K. (2018). Az innováció értelmezése a turizmusbiztonság területén - különös tekintettel az oktatás és a kutatás területére [The Interpretation of Innovation in the Field of Tourism Safety and Security - with Special Focus on the Fields of Education and Research], Rendörségi Tanulmányok, 1(3), 71-80.

Blom, T. (2000). Morbid tourism - a postmodern market niche with an example from Althorp. Nork Geografisk Tidsskrift - Norwegian Journal of Geography. 54(1), 29-36.

Breda, Z., \& Costa, C. (2005). Safety and Security Issues Affecting Inbound Tourism in the People's Republic of China in Mansfeld, Y. \& Pizam, A. (Ed.), Tourism, Safety and Security: From Theory to Practice. Butterworth-Heinemann.

Budapest Mysterium Tours (2020). Bloody Tales from within the Castle Walls. Retrieved from: https://www.mysteriumtours.com/budapest/ (13.02. 2020)

Budapest Scenes (2020). Túráink [Our Tours]. Retrieved from: https://www.budapestscenes.com/ (13.02. 2020)

Cohen, E. H. (2011). Educational dark tourism at in populo site - The Holocaust Museum in Jerusalem. Annual of Tourism Research, 38(1), 193-209.

Crompton, J. (1979). Motivations for Pleasure Vacations. Annals of Tourism Research, 4, 408424.

Dann, G. M. S. (1994). Tourism: The nostalgia industry of the future. In. W Theobald (Ed.), Global tourism: The next decade (pp. 55-67). Oxford: Butterworth Heinemann.

Dark-tourism website: Retrieved from: http://www.dark-tourism.com/, (11.09.2019)

Deerwester, J. (2019). Chernobyl snags 19 Emmy nominations, inspiring tourism wave. But is disaster site safe? Retrieved from: USA TODAY: https://eu.usatoday.com/story/travel/destinations/2019/07/15/chernobyl-becomeofficial-tourist-attraction-but-safe/1712623001/, (02.09.2019)

Fall, L. T., \& Massey, K. E. (2005). The Significance of Crisis Communication in the Aftermath of 9/11: A National Investigation of How Tourism Managers Have Re-Tooled Their Promotional Campaigns. Journal of Travel \& Tourism Marketing, 19, 2-3, 77-90.

Farmaki, A. (2013). Dark tourism revisited: a supply/ demand conceptualization. International Journal of Culture, Tourism and Hospitality Research, 7(3), 281-292.

Fiumei úti sírkert website (2020). A Fiumei úti sírkert [The Fiume Graveyard]. Retrieved from: https://fiumeiutisirkert.nori.gov.hu/ (13. 02. 2020)

Friedrich, M., \& . Jonhston, T. (2013). Beauty versus tragedy. Thanatourism and the memorialization of the 1944 Rwandan genocide. Journal of Tourism and Cultural Change, 11(4), 302-320.

Fuchs, G., \& Reichel, A. (2011). An exploratory inquiry into destination risk perceptions and risk reduction strategies of first time vs. repeat visitors to a highly volatile destination. Tourism Management, 32, 266-276.

Henderson, J.C. (2003). Communicating in a crisis SQ 006. Tourism Management, 24, 279287.

Holokauszt Emlékközpont website (2020.): Rólunk [About us]. Retrieved from: http://hdke.hu/rolunk (13. 02. 2020)

Hostelworld (2020). War Hostel. Retrieved from: https://www.hostelworld.com/hosteldetails.php/War-Hostel/Sarajevo/98269 (14. 02. 2020) 
Imagine Budapest (2020). Budapest Sightseeing Tours. Retrieved from: http://imaginebudapest.hu/ (13.02. 2020)

Karl, M., \& Schmude, J. (2017). Understanding the role of risk (perception) in destination choice: A literature review and synthesis. Tourism Review, 65(2), 138-155.

Light, T. (2017). Progress in dark tourism and thanatourism research: An uneasy relationship with heritage tourism. Tourism Management, 61, 275-301.

Mansfeld, Y., \& Pizam, A. (2006). Tourism Security and Safety: From Theory to Practice. In Mansfeld, Y., \& Pizam, A. (Ed), Tourism, Safety and Security, 139-141. Burlington MA.

Marton, Z., Keller, K., \& Birkner, Z. (2018). A turizmusbiztonságban rejlö marketing és menedzsment implikációk [Marketing Implications in the Field of Tourism Safety and Security], TURIZMUS BULLETIN, 18 (2), 12-20.

Massey, J. (2005). The airline industry in crisis: Analysing the response to the September 11th attacks on the U.S. Journal of Hospitality and Leisure Marketing, 12(162), 97-114.

Mohácsi Nemzeti Emlékhely (2020). Retrieved from: https://www.mohacsiemlekhely.hu/

Murarégió Turisztikai Portál (2020). Bunkerturizmus [Bunker Tourism]. Retrieved from: http://www.muraregio.hu/bunkerturizmus (13. 02. 2020)

Péter, E., Német, K., Katona, A., Göllény-Kovács, N., \& Lelkóné Tollár, I. (2019). How people in Zala county see security in tourism. DETUROPE: Central European Journal of Tourism and Regional Development, 11(1), 95-116.

Péter, E., Németh, K., \& Lelkóné Tollár, I. (2018). Turizmusbiztonság, mint újonnan felmerülő fogyasztói igény [Tourism Safety as a New Consumer Need]. TURIZMUS BULLETIN, 18(, 2), 30-37.

Prentice, R. (1993). Tourism and heritage attractions. London, Routledge.

Reményik, B., \& Dávid, L. (2014). A thanaturizmus fejlesztési lehetőségei Kelet-KözépEurópában [The Development Opportunities of Thanatourism in East-Central Europe]. In M. Jászberényi, M. (Ed.), A kulturális turizmus sokszinüsége [The Diversity of Cultural Tourism] (pp. 203-215). Budapest: Nemzeti Közszolgálati és Tankönyv Kiadó.

Rucinska, D. (2016). Natural Disaster Tourism as a Type of Dark Tourism. International Journal of Humanities and Social Sciences, 10(5), 1458-1462.

Seaton, A. (1999). War and thanatourism: Waterloo 1815-1914. Annals of Tourism Research, 26(1), 1, 234-244. p.

Sönmez, S. F., \& Graefe, A.R. (1998). Influence of terrorism risk on foreign tourism decisions. Annals of Tourism Research, 25, 112-144.

Stebbins, R. A., \& Rojek, C., \& Sullivan, A. M. (2006). Leisure/Loisir. 30, 3-231.

Stone, P. (2005). Review: Dark tourism - cashing in on tragedy. Tourism Society Seminar Event. Retrieved from https://www.dark-tourism.org.uk/ at 10.10.2019

Stone, P. (2006). A dark tourism spectrum. Towards a typology of death and macabre related tourist sites, attractions and exhibitions. Tourism, 52, 145-160.

Stone, P. R., \& Sharpley, R. (2013). Deviance, Dark Tourism and Dark Leisure: Towards (re)configuration of morality and the taboo in secular society. In S, Elkington \& Grammon, S. (Ed), Contemporary Perspectives in Leisure: Meanings, Motives and Lifelong Learning. Abington, Oxon: Routledge.

Stone, P., \& Sharpley, R. (2008). CONSUMING DARK TOURISM: A Thanatological Perspective. Annuals of Tourism Research, 35(2), 574-595.

Tenczer, G. (2019). Meghívás egy gyilkos Halál-túrára [Invitation for a killer death tour]. Retrieved from: https://index.hu/kultur/eletmod/2019/09/28/teve_helyett_halaltura a pilisben/ (20.10.2019)

Terror Háza Múzeum (2020). The History of the Museum. Retrieved from: https://www.terrorhaza.hu (13. 02. 2020) 
Tilkovszky, L. (1998). Nemzetiségi politika a 20. században [Nationality Policy in the $20^{\text {th }}$ Century]. Csokonai Kiadó. Budapest. 285 p.

Turizmus Online (2013). Szellemjárta hotelek a Booking.com-nál [Ghost Hotels of Booking.com]. Retrieved from: http://turizmusonline.hu/hotelszalloda/cikk/szellemjarta_hotelek_a_booking_nal (14.02. 2020)

World Tourism Organization - UNWTO (2019). International Tourism Highlights - 2019 Edition. Available at: https://www.e-unwto.org/doi/pdf/10.18111/9789284421152, Retrieved at: 08.09.2019

Yang, E. C. L., \& Nair, V. (2014). Tourism at risk: A Review of Risk and Perceived Risk in Tourism. Asia-pacific Journal of Innovations in Hospitality and Tourism, 3(2), 2, 239259.

Yoshida, K., Bui, H. T., \& Lee, J. T. (2016). Does tourism illuminate the darkness of Hiroshima and Nagasaki? Journal of Destination Marketing \& Management, 53, 333-340. 